\title{
Effect of HGH replacement therapy on concentration of 15 serum proteins
}

\author{
H. G. MINCHIN CLARKE, D. B. GRANT, and D. PUTMAN \\ From the Clinical Research Centre, Watford Road, Harrow, Middlesex
}

\begin{abstract}
Minchin Clarke, H. G., Grant, D. B., and Putman, D. (1973). Archives of Disease in Childhood, 48, 608. Effect of HGH replacement therapy on concentration of 15 serum proteins. The effect of human growth hormone (HGH) therapy on the concentration of 15 individual serum proteins was studied in $13 \mathrm{HGH}-$ deficient children. After 3 months' HGH therapy, 8 patients with isolated HGH deficiency showed a marked rise in serum transferrin with less striking changes in haptoglobin, haemopexin, IgG, and proteins numbered 41 and 45 . No significant changes in these proteins were found in 5 patients with craniopharyngioma or generalized anterior pituitary failure.
\end{abstract}

The importance of growth hormone in protein metabolism has been recognized for many years, but little is known about the effects of human growth hormone $(\mathrm{HGH})$ on serum protein concentration in man. Though Drash (1968) observed no change in the levels of albumin and globulin in hypopituitary patients treated with $\mathrm{HGH}$, we considered it of interest to study the concentration of a number of serum proteins in patients receiving HGH therapy.

Patients and methods

Thirteen patients with evidence of HGH deficiency (Tanner et al., 1971) were studied: 8 appeared to have

Received 4 January 1973. isolated HGH deficiency, 2 had more generalized anterior pituitary failure, and in $3 \mathrm{HGH}$ deficiency was due to craniopharyngioma. Details of therapy and growth acceleration during the first 6 months of treatment are given in Table I

Blood samples were collected by finger-prick before HGH therapy was begun and again after 3 months' treatment. The concentration of the following serum globulins was estimated by a modification of Laurell's quantitative immunoelectrophoresis (Clarke and

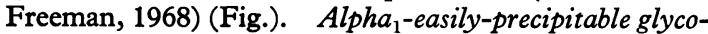
protein ( $a_{1} \mathrm{PGp}$ ); Gc-globulin (Gc); alpha $a_{2}$-macroglobulin $\left(a_{2} \mathrm{M}\right)$; caeruloplasmin (Caer); haptoglobin (Hpt); transferrin (Trf); haemopexin ( $\mathrm{Hpx})$; beta-lipoprotein $(\beta L \mathrm{p})$, and proteins numbered $9,41,45,53$, and 99 (Freeman and Smith, 1970).

TABLE I

Clinical details in 13 patients receiving $H G H$ treatment

\begin{tabular}{|c|c|c|c|c|c|}
\hline $\begin{array}{c}\text { Case } \\
\text { no. }\end{array}$ & Diagnosis & $\begin{array}{c}\text { Age at start } \\
\text { of treatment } \\
(y r)\end{array}$ & $\begin{array}{l}\text { Increase in } \\
\text { growth velocity } \\
\text { during } 1 \mathrm{st} 6 \mathrm{mth} \\
\mathrm{HGH} \text { therapy } \\
(\mathrm{cm} / \mathrm{yr})\end{array}$ & $\begin{array}{c}\text { Weekly } \\
\text { dose of } \\
\text { HGH } \\
\text { (IU) }\end{array}$ & Other treatment \\
\hline $\begin{array}{r}1 \\
2 \\
3 \\
4 \\
5 \\
6 \\
7 \\
8 \\
9 \\
10 \\
11 \\
12 \\
13\end{array}$ & $\begin{array}{l}\text { Isolated HGH deficiency } \\
\text { Isolated HGH deficiency } \\
\text { Isolated HGH deficiency } \\
\text { Isolated HGH deficiency } \\
\text { Isolated HGH deficiency } \\
\text { Isolated HGH deficiency } \\
\text { Isolated HGH deficiency } \\
\text { Isolated HGH deficiency } \\
\text { General anterior pituitary failure } \\
\text { General anterior pituitary failure } \\
\text { Craniopharyngioma } \\
\text { Craniopharyngioma } \\
\text { Craniopharyngioma }\end{array}$ & $\begin{array}{r}7 \cdot 1 \\
8 \cdot 5 \\
9 \cdot 2 \\
9 \cdot 3 \\
12 \cdot 5 \\
15 \cdot 5 \\
17 \cdot 9 \\
17 \cdot 9 \\
4 \cdot 0 \\
7 \cdot 8 \\
13 \cdot 0 \\
17 \cdot 2 \\
24 \cdot 5\end{array}$ & $\begin{array}{r}8 \cdot 4 \\
4 \cdot 2 \\
8 \cdot 4 \\
6 \cdot 2 \\
5 \cdot 0 \\
3 \cdot 2 \\
3 \cdot 6 \\
1 \cdot 8 \\
15 \cdot 2 \\
9 \cdot 2 \\
8 \cdot 8 \\
4 \cdot 0 \\
1 \cdot 6\end{array}$ & $\begin{array}{l}20 \\
20 \\
20 \\
10 \\
20 \\
10 \\
10 \\
20 \\
20 \\
20 \\
20 \\
10 \\
20\end{array}$ & $\begin{array}{c}\text { Nil } \\
\text { Nil } \\
\text { Nil } \\
\text { Nil } \\
\text { Nil } \\
\text { Nil } \\
\text { Nil } \\
\text { Nil } \\
\text { Cortisone acetate } \\
\text { Cortisone acetate and thyroxine } \\
\text { Nil } \\
\text { Cortisone acetate and thyroxine } \\
\text { Nil }\end{array}$ \\
\hline
\end{tabular}




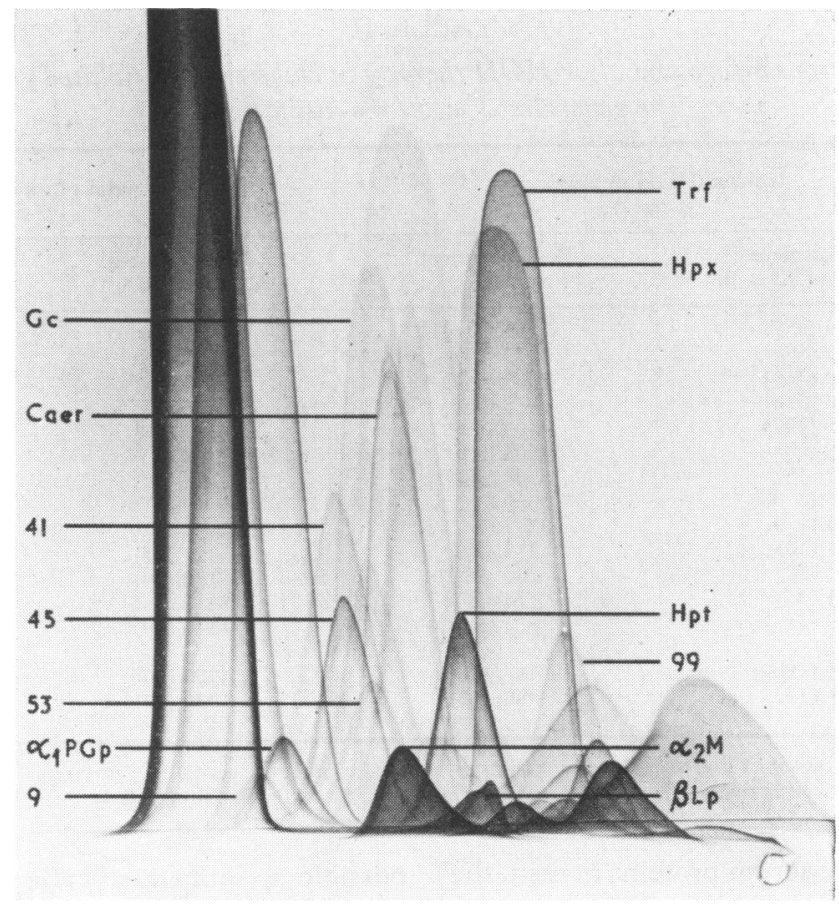

FIG.-Laurell electrophoresis of human serum.

Using this technique measurements cannot be given in absolute units, and results have been expressed in arbitrary units derived from the area under each protein peak.

The concentration of serum albumin (Alb) and $\gamma$ G-immunoglobulin (IgG) was measured by the radial immunodiffusion method of Mancini, Carbonara, and Heremans (1965) using commercially available standards (Behringwerke AG).

The results were analysed using Student's paired ' $t$ ' test.

\section{Results}

Patients with isolated HGH deficiency. The results obtained in 8 patients with isolated HGH deficiency are summarized in Table II.

Each patient showed a rise in serum transferrin during therapy and the mean value after 3 months was higher than the pretreatment value $(P<0.001)$. A correlation was obtained between percentage change in transferrin concentration and increase in growth rate during the first 6 months of treatment $(r=0 \cdot 79, P=0 \cdot 02)$.

The mean values for haemopexin and protein number 41 also rose during treatment $(P<0.05)$.

The mean values for IgG, haptoglobin, and protein number 45 decreased during treatment $(\mathrm{P}<0.05)$. One patient (Case 8$)$ had subnormal levels of IgG both before and after treatment (210-300 mg/100 ml).

Patients with craniopharyngioma or complete anterior pituitary failure. The mean values and SD for protein concentration before and after therapy are also given in Table II. No significant changes were shown in this group. In particular, there was no appreciable change in serum transferrin in the 2 patients with generalized anterior pituitary failure.

\section{Discussion}

It is widely accepted that growth hormone stimulates protein synthesis in vivo, but it is still uncertain whether this action is due to growth hormone itself or whether it is brought about by an intermediary such as sulphation factor (Daughaday, 1971). Using perfusion experiments, Clemens and Korner (1970) showed that growth hormone only increased liver protein synthesis in the presence of supplementary amino acids, while John and Miller (1969) found that growth hormone had no effect on the synthesis of plasma or liver proteins.

Although the present studies do not permit any conclusion on the effects of $\mathrm{HGH}$ on the rates of 
TABLE II

Serum protein concentrations before and after HGH therapy in children with isolated growth hormone deficiency or generalized pituitary insufficiency

\begin{tabular}{|c|c|c|c|c|}
\hline & \multicolumn{2}{|c|}{$\begin{array}{l}\text { Isolated HGH deficiency } \\
\text { (8 cases) }\end{array}$} & \multicolumn{2}{|c|}{$\begin{array}{l}\text { General pituitary insufficiency } \\
\text { ( } 5 \text { cases })\end{array}$} \\
\hline & $\begin{array}{l}\text { Pretreatment } \\
\text { mean (SD) }\end{array}$ & $\begin{array}{l}\text { Post-treatment } \\
\text { mean (SD) }\end{array}$ & $\begin{array}{c}\text { Pretreatment } \\
\text { mean }(\mathrm{SD})\end{array}$ & $\begin{array}{l}\text { Post-treatment } \\
\text { mean (SD) }\end{array}$ \\
\hline $\begin{array}{l}\alpha_{1} \text { PGp } \\
\text { Gc } \\
\text { Caer } \\
\alpha_{2} M \\
\text { Hpt } \\
\text { Hpx } \\
\text { Trf } \\
\beta \text { Lp } \\
9 \\
41 \\
45 \\
53 \\
99\end{array}$ & $\begin{array}{c}51 \cdot 4(8 \cdot 7) \\
408(59) \\
24 \cdot 0(3 \cdot 4) \\
55 \cdot 3(9 \cdot 8) \\
205(107) \\
448(68) \\
392(55) \\
27 \cdot 3(8 \cdot 3) \\
25 \cdot 0(7 \cdot 9) \\
189(40) \\
139(32) \\
91(35) \\
120(31)\end{array}$ & $\begin{array}{c}51 \cdot 1(7 \cdot 6) \\
378(29) \\
23 \cdot 8(3 \cdot 7) \\
60 \cdot 8(5 \cdot 8) \\
103(60)^{\star} \\
508(39)^{\star} \\
508(38) \dagger \\
30 \cdot 9(5 \cdot 1) \\
27 \cdot 7(5 \cdot 2) \\
214(20)^{\star} \\
100(18)^{\star} \\
74(14) \\
112(18)\end{array}$ & $\begin{array}{c}61 \cdot 2(10 \cdot 8) \\
392(68) \\
30 \cdot 5(4 \cdot 0) \\
58 \cdot 6(13 \cdot 6) \\
181(51) \\
482(33) \\
431(41) \\
30 \cdot 5(5 \cdot 4) \\
24 \cdot 4(7 \cdot 9) \\
221(31) \\
132(24) \\
88 \cdot 2(4 \cdot 1) \\
140(39)\end{array}$ & $\begin{array}{c}52 \cdot 8(6 \cdot 7) \\
378(45) \\
27 \cdot 9(3 \cdot 4) \\
55 \cdot 0(11 \cdot 7) \\
164(35) \\
473(85) \\
485(62) \\
28 \cdot 2(4 \cdot 1) \\
24 \cdot 2(8 \cdot 0) \\
175(31) \\
113(11) \\
80 \cdot 1(12 \cdot 7) \\
128(23)\end{array}$ \\
\hline $\begin{array}{l}\text { Albumin } \\
\text { IgG }\end{array}$ & $\begin{array}{l}5100(1800) \\
1211(543)\end{array}$ & $\begin{array}{r}4790(1000) \\
906(443)^{\star}\end{array}$ & $\begin{array}{l}4720(500) \\
1030(301)\end{array}$ & $\begin{array}{r}4925(400) \\
925(445)\end{array}$ \\
\hline
\end{tabular}

Note: Albumin and $\mathrm{IgG}$ expressed in $\mathrm{mg} / 100 \mathrm{ml}$ and remaining proteins in arbitrary units.

Significance of difference between pre- and post-treatment concentration: ${ }^{\star} P<0.05,+P<0.001$.

synthesis and turnover of serum proteins in man, the results suggest that the metabolism of some serum proteins may be modified by $\mathrm{HGH}$ replacement therapy. Nevertheless, it must be appreciated that significant protein changes were seen only in patients with isolated HGH deficiency, and not in those where the hormone deficiency was secondary to pituitary pathology, such as craniopharyngioma. The most striking finding was an increase in serum transferrin during treatment, particularly in patients with isolated $\mathrm{HGH}$ deficiency. A similar rise in transferrin, associated with an increase in red cell mass, was described by Jepson and McGarry (1972) in a group of hypopituitary subjects treated with $\mathrm{HGH}$. It seems likely that this rise in transferrin is related to increased iron turnover, secondary to increased haemoglobin synthesis. Similarly, the changes in haptoglobin and haemopexin found in patients with isolated $\mathrm{HGH}$ deficiency were probably related to changes in red cell metabolism after HGH therapy. Red cell mass is also dependent on thyroid function (Muldowney, Crooks, and Wayne, 1957), but it is unlikely that the inconsistent results obtained with general anterior pituitary failure were due to secondary hypothyroidism; 3 patients had normal plasma thyroxine levels and the other 2 were receiving replacement therapy with thyroxine.

The significance of the modest changes in proteins 41 and 45 in patients with isolated growth hormone deficiency is uncertain. It was not possible to obtain suitable controls from normal children for this study, but comparison with adult control serum indicated that the changes in these proteins represented a return to normal levels during treatment. Protein 45 has been found to rise during acute phase response to trauma (Clarke, Freeman, and Pryse-Phillips, 1971) and has been tentatively identified as antichymotrypsin (Laurell, 1972).

Our failure to find any consistent changes in serum albumin during $\mathrm{HGH}$ replacement therapy is in agreement with results given by Drash (1968), and it appears that $\mathrm{HGH}$ has little effect on serum albumin concentration in man.

Pierpaoli and Sorkin (1969) have reported that adult mice treated with antibovine growth hormone serum show reduced levels of antibody synthesis. The above results indicate that $\mathrm{HGH}$ deficiency is not associated with depressed serum IgG levels which can be corrected by $\mathrm{HGH}$ therapy. Serum IgG levels were normal in all but one of our patients, and appeared to fall during treatment.

We thank Professor J. M. Tanner and Mr. R. H. Whitehouse for allowing us to use their clinical data.

\section{REFERENCES}

Clarke, H. G. M., and Freeman, T. (1968). Quantitative immunoelectrophoresis of human serum proteins. Clinical Science, 35, 403.

Clarke, H. G. M., Freeman, T., and Pryse-Phillips, W. (1971). Serum protein changes after injury. Clinical Science, 40, 337. 
Clemens, M. J., and Korner, A. (1970). Amino acid requirement for the growth-hormone stimulation of incorporation of precursors into protein and nucleic acids of liver slices. Biochemical Fournal, 119, 629.

Daughaday, W. H. (1971). Sulfation factor regulation of skeletal growth. A stable mechanism dependent on intermittent growth hormone secretion. American fournal of Medicine, 50, 277.

Drash, A. (1968). Evaluation of patients in the routine chemical laboratory. In Human Growth, p. 98. Ed. by D. B. Cheek. Lea and Febiger, Philadelphia.

Freeman, T., and Smith, J. (1970). Human serum protein fractionation by gel filtration. Biochemical fournal, 118, 869.

Jepson, J. H., and McGarry, E. E. (1972). Hemopoiesis in pituitary dwarfs treated with human growth hormone and testosterone. Blood, 39, 238.

John, D. W., and Miller, L. L. (1969). Regulation of net biosynthesis of serum albumin and acute phase plasma proteins. Fournal of Biological Chemistry, 244, 6134.

Laurell, C. B. (1972). Electrophoretic and electro-immunochemical analysis of proteins. Scandinavian fournal of Clinical and Laboratory Investigation, 29, Suppl. 124, 134.
Mancini, G., Carbonara, A. O., and Heremans, J. F. (1965). Immunochemical quantitation of antigens by single radial immunodiffusion. Immunochemistry, 2, 235.

Muldowney, F. P., Crooks, J., and Wayne, E. J. (1957). The total red cell mass in thyrotoxicosis and myxoedema. Clinical Science, 16, 309.

Pierpaoli, W., and Sorkin, E. (1969). Effect of growth hormone and anti-growth hormone serum on the lymphatic tissue and the immune response. Antibiotica et Chemotherapia, 15, 122.

Tanner, J. M., Whitehouse, R. H., Hughes, P. C. R., and Vince, F. P. (1971). Effect of human growth hormone treatment for 1 to 7 years on growth of 100 children, with growth hormone deficiency, low birthweight, inherited smallness, Turner's syndrome, and other complaints. Archives of Disease in Childhood, 46, 745.

Correspondence to Dr. H. G. M. Clarke, Clinical Research Centre, Watford Road, Harrow, Middlesex HA1 3UJ. 